\title{
PUBLIC ENGAGEMENT IN THE POLICY OF ARRANGEMENT AND EMPOWERMENT FOR STREET VENDORS IN GARUT KOTA SUBDISTRICT
}

\author{
Kurnia Muhamad Ramdhan, Budiman Rusli, and
}

Fakultas Ilmu Sosial dan Ilmu Politik, Universitas Padjadjaran, Jl. Raya Bandung-Sumedang KM. 21 Jatinangor, 456363

E-mail: kurniamr@yahoo.com ; budiman.rusli@unpad.ac.id ; ahmad_buchari@yahoo.com

\begin{abstract}
This paper aims to examine the cause of public engagement ineffectiveness in the policy of arrangement and empowerment for street vendors in Garut Kota subdistrict. The research method used is descriptive qualitative. Based on the results of the study, it can be concluded that public engagement in this policy has not been effective, because it has not been related to: 1) Context and Settings; 2) Sponsors, Conveners, and Their Motivations for Direct Public Engagement; 3) Process Design; and 4) Outcomes. Regarding Context and Settings, there are no specific rules for public engagement. Public engagement has become a formality to fulfill the principles of democratic governance, but most of the local government decisions and actions that are considered crucial in this policy do not represent street vendors desire. Regarding Sponsors, Conveners, and Their Motivations for Direct Public Engagement, public engagement in the policy does not have sponsors yet in its sustainability, as for those who are organizers of public engagement in this policy based on the Regent's Decree, especially in the fields that give positions to street vendors to be engaged as implementing elements. Some information, related to Process Design and Outcomes, is challenging to obtain. In substance, the author does not find information that is genuinely relevant to the aspects contained therein. The author recommends that a comprehensive review be carried out to formulate the Implementation Guidelines and Technical Guidelines based on the elements set out in the framework of direct public engagement as a guideline for conducting public engagement.
\end{abstract}

Key words: public engagement; street vendors; arrangement and empowerment policies; garut kota

\section{KETERLIBATAN PUBLIK DALAM KEBIJAKAN PENATAAN DAN PEMBERDAYAAN PEDAGANG KAKI LIMA DI KECAMATAN GARUT KOTA}

\begin{abstract}
ABSTRAK. Tulisan ini bertujuan untuk mengkaji penyebab belum efektifnya keterlibatan publik dalam kebijakan penataan dan pemberdayaan PKL di Kecamatan Garut Kota. Adapun metode penelitian yang digunakan ialah deskriptif kualitatif. Berdasarkan hasil penelitian, dapat disimpulkan bahwa keterlibatan publik dalam kebijakan ini belum berjalan efektif, karena belum berkaitan dengan: 1) Context and Setting; 2) Sponsors, Conveners, and Their Motivations for Direct Public Engagement; 3) Process Design; dan 4) Outcomes. Mengenai Context and Setting, tidak ada satu pun aturan yang khusus mengatur terkait keterlibatan publik. Keterlibatan publik menjadi sebatas formalitas untuk memenuhi asas pemerintahan yang demokratis, namun sebagian besar keputusan dan tindakan Pemkab Garut yang dianggap krusial dalam kebijakan ini tidak merepresentasikan kehendak para PKL. Mengenai Sponsors, Conveners, and Their Motivations for Direct Public Engagement, keterlibatan publik dalam kebijakan ini belum memiliki sponsor dalam keberlangsungannya, adapun mengenai pihak yang menjadi penyelenggara keterlibatan publik dalam kebijakan ini berdasarkan Kepbup tersebut, yaitu Tim Penataan dan Pemberdayaan PKL Kabupaten Garut, khususnya pada bidang yang memberikan kedudukan bagi para PKL untuk terlibat sebagai unsur pelaksana. Beberapa informasi terkait dengan Process Design dan Outcomes menjadi sulit untuk diperoleh, pada substansinya Penulis tidak menemukan informasi yang benar-benar relevan dengan aspek-aspek yang terdapat di dalamnya. Penulis merekomendasikan agar dilakukan pengkajian menyeluruh guna merumuskan Petunjuk Pelaksanaan dan Petunjuk Teknis berdasarkan aspek-aspek yang tertuang dalam kerangka kerja direct public engagement sebagai pedoman dalam melakukan keterlibatan publik.
\end{abstract}

Kata kunci: keterlibatan publik; pedagang kaki lima; kebijakan penataan dan pemberdayaan; garut kota

\section{INTRODUCTION}

Various methods are used by the people of Garut Regency to survive, the narrowing of jobs, and the transformation of skilled resources into machines. The diversity that is a real portrait of the heterogeneity in urban areas, not least in terms of earning a living which is reflected in the phenomenon of street vendors in Garut Kota Subdistrict as one source of livelihood in Garut Regency.

The existence of street vendors in Garut Kota Subdistrict is not without cause, the rise of street vendors who sell their goods in line with the development of urban human population, which is increasing without being matched by the availability of jobs and other sources of livelihood. Street Vendors, including small businesses that are profit-oriented like an entrepreneur (Santoso \& Harsono,
2014). Its existence is inseparable from the long history of the Regency's journey since the colonial period until now. Over time, street vendors in Garut Kota developed rapidly to cause the density in eight red-zone points, namely: 1) Jend. A. Yani street; 2) Mandalagiri street; 3) Pasar Baru street; 4) Ciwalen street; 5) Siliwangi street; 6) Kiansantang street; 7) Cikuray street; and 8) Ciledug street. The total data of street vendors in Garut Kota Subdistrict based on the latest data in 2015 was 1,318 traders (Department of Industry, Trade and ESDM Garut, 2015).

The existence of street vendors seems to be a dilemma for the local government. The rise of street vendors who crowded the heart of the city, on the one hand has a positive impact on the economy, both small and medium scale. Still, on the other hand the rampant of street vendors who sell on the roadside raises a complicated problem and 
becomes one of the priorities of handling due to clutter street vendors have an impact on decreasing urban aesthetic value, narrowing of shoulders and road, and reflecting urban slums. This understanding needs to be supported through positive behavior from traders as a tangible contribution to participating in maintaining city hygiene, by understanding the importance of cleanliness of the city both in relation to health, beauty and compliance in the implementation of government policies, is a necessity for citizens including traders in the city centre to also help local governments in maintaining cleanliness (Areros, 2015).

Garut Kota Subdistrict chaos by street vendors is a classic problem that has been documented since 1895 (Koninklijk Instituut voor Taal-, Land- en Volkenkunde (KITLV) Digital Image Library, 1895), until 1935 there was a report that street vendors began to be banned in the city of Garut by the Colonial Government at that time (De tribune: soc. dem. Weekblad, 1935). In 1935, traders were prohibited from selling their wares on the sidewalk. Every trader must trade indoors (shops, stalls). The phenomenon is increasingly rolling along with changing times, the unavailability of a place for traders to peddle their wares is one of the reasons why street vendors insist on selling in places that are not allowed. To solve the problem, the local government seeks to find the right solution in the efforts to protect, control and guide street vendors, one of them is by relocating street vendors to several locations and buildings that have been provided.

As mandated in Presidential Decree Number 125 of 2012 concerning Coordination of Structuring and Empowering Street Vendors, and Ministry of Home Affairs's Decree Number 41 of 2012 concerning Guidelines for Arrangement and Empowerment of Street Vendors, that the increase in the number of street vendors in the regions has affected the disruption of traffic, aesthetics and cleanliness, and the function of urban area infrastructure, it is necessary to arrange this street vendor. Based on these laws, the local government has expressed its desire to organize the city centre from the excesses generated by street vendors through the Local Government Regulation Number 3 of 2014 concerning the local government Medium Term Strategic Plan for Year 2014-2019 and reinforced by the Local Government Regulation Number 18 of 2017 concerning Amendments to Regulation Number 12 of 2015 concerning Order, Cleanliness, and Beauty, which was then more concretized again through three Garut Regent Decrees, namely:

1) Regent's Decree Number 511.23/ Kep. 790-Admrek/ 2014 concerning the Team of Arrangement and Empowerment for Street Vendors in Garut Regency;

2) Regent's Decree Number 511.3/ Kep. 201-Satpol PP/ 2015 concerning the Team of Security and Control for Street Vendors in Garut Regency; and

3) Regent's Decree Number 511.23/ Kep. 528-Admrek/ 2015 concerning Determination of Temporary Locations for Street Vendors Business Activities in the Garut Kota Subdistrict.
In addition, be found an Appeal Letter Number 300/ 173-Satpol PP/ 2016 addressed to the people to jointly realize Garut Bermartabat Nyaman dan Sejahtera, Garut Caang Pengkolan Lenglang.

The control effort carried out since 2014 has a significant impact, especially on the livelihoods of the street vendors. Based on preliminary observations in the field, the location of buildings which were projected as street vendors relocation sites were quietly neglected, whereas street vendors returned to crowded eight redzone points that were previously prohibited by the local government. Since it was inaugurated three years ago, the existence of these two street vendors buildings in Babakan Pajagalan, seems to be neglected. As many as 288 stalls destined for street vendors looked dusty and dirty. In fact, some building facilities such as the roof, the rolling door, the guardrail, and the building look damaged. Some elementary school children from the school next to the building often make the street vendor building area a playground. Some illegal parking points are unstoppable for storing various types of private vehicles. While late at night, the area of the building is often used as a youth hangout arena, which sometimes ends up being used as a place of immorality such as drinking and sordid locations (Supriadin, 2018). Responding to this, The Civil Service Police Unit often patrols to the area in question, even had a chance to catch prostitutes who were hanging out there, including a number of punk kids sleeping in the street vendor building (Herdiana, 2018). This certainly becomes an irony, on one side of the building was built to accommodate the street vendors who were relocated, but on the other side of the building was abandoned and almost neglected, even a place of immorality. The reason street vendors are reluctant to occupy was revealed by the Vice Regent of Garut, that traders are reluctant to occupy the building because selling on the street is more profitable than selling in a relocation building (Baihaqi, 2018).

Apart from talking about the impact of the implementation of this policy on street vendors, the existence of street vendors who sell in the red zone causes chaos in the cities. The sidewalks as pedestrians are partially covered by street vendors, so that the pedestrian's right to enjoy comfortable and safe walking facilities is also snatched, likewise with the shoulders and the road, narrowing the speed of motorized vehicles resulting in congestion on the streets of the capital. The face of the shops on the side of the road was also affected, covered by tents and street vendors, giving the impression of slums and merchandise in the shops became less exposed. Some street vendors even assemble electricity installations as a stall lighting facility, and this can trigger a short circuit and is dangerous to pedestrians and shops in the vicinity.

High hopes are built up through the implementation of this Street Vendor Merchant empowerment and arrangement policy to alleviate the problems caused by the presence of street vendors in the red zone. But until now, 
this policy has not found the expected results in practice, the street vendors have gone back to the red-zone to make a living, a policy with common sense has not yet formed that can bridge the desires and needs of both parties to make this policy ineffective. The failure to implement the policy on structuring and empowering street vendors is also recognized by the Regent of Garut on August 14, 2017 (Suryarandika, 2017).

Normatively, thelack of engagement of streetvendors in planning, decision making, policy implementation, as well as monitoring and evaluation of the regulation and empowerment of street vendors is possible because the rules governing the rights and obligations of street vendors have not provided room for engagement of street vendors. As a derivative rule, Regent's Decree Number 511.23/ Kep. 790-Admrek/ 2014 provides room for street vendors to get engaged through two of the three fields contained in the team, namely:

1) Field of Socialization, Data Collection, andArrangement; and

2) Field of Structuring/ Relocation Operations.

As for one other sector, namely the Empowerment and Development Sector after Post Arrangement/ Relocation, the street vendors have not been given space to be engaged.

The Civil Service Police Unit of Garut Regency as the coordinator of the Structuring/ Relocation Operations Division on the team participated in conducting socialization, notification, and invitations to the street vendors to work together to arrange the arrangement, wheels and other tools like tents can be arranged and stored in a safe place also looks neat (Prasetio, 2018). In order to increase the effectiveness of these activities, The Civil Service Police Unit worked closely with the ranks of the Military and Police (Department of Communication and Information Garut, 2018).

Based on observations in the field, starting from June to September 2019 the theft area along Achmad Yani street seems deserted from the presence of street vendors, this is because the local government has intensified its policy of arrangement and empowerment for street vendors who have experienced a vacuum for two years. Now along the road is guarded by The Civil Service Police Unit personnel. Almost every 50 meters of the road are installed restrictions on street vendors activities. Helmi Budiman as Vice Regent of Garut promised to be consistent in implementing the policy in stages, temporarily controlling and patrolling it in Alun-alun until the Ciledug T-junction in stages. Helmi said that his party encourages traders to utilize the street vendor building, which was completed two years ago. The traders themselves claimed to be reluctant to sell in the building. Because the subscription is considered quiet and access to the building is very complicated. According to the explanation of one of the street vendors on Achmad Yani street, Supriatna (33), there are three factors that cause street vendors to be reluctant to occupy the building. The first is a quiet subscription, and the second is complicated, the third community who shop requires several times access to public transportation to arrive at the location. Finally, the public chose not to shop (Ghani, 2019).

The exclusion of street vendors from the planning, decision making, policy implementation, and policy monitoring and evaluation stages has not enabled this policy to be implemented effectively so that the output and outcome of the policy have not been aligned with the policy objectives. Incompatible expectations from the policy target groups with the Government's expectations are possible if the policy target groups are lacking or have never been engaged.

Public policy is a factor that leveraged the life together, is a critical factor for the progress or decline of the nation, no matter how great democracy if the political system is not able to develop superior public policy, it is useless (Rusli, 2015). In another definition, a policy is a set of decisions or actions that are intentionally taken by a person, group, or government regarding a method to achieve several goals or objectives in a particular situation (Anderson, 2006).

According to Dahlgren (2009), civic identity emerges in the process of doing something together by collective engagement, to gain a sense of empowerment and awareness of influencing the process. Community empowerment also implies changes in city government, which are asked to engage with active citizens who challenge the consolidated routines and attitudes of civil servants (Bartoletti and Faccioli, 2016).

Nelson and Wright (1995) emphasize the process of public engagement as a transformative tool for social change. Also, public engagement is intended to produce better decisions, and thus efficiency is more beneficial for the whole community (Beierle, 1999; Thomas, 1995). Irvin (2004) argues that the benefits of citizen engagement can only increase if public engagement is characterized by discussion and exchange of arguments in which individuals justify their opinions and are ready to modify their position. Discussion participants can analyze problems, discuss problems, and offer solutions that make sense for them. This has the potential to stimulate public reasoning freely, equally, inclusive in different interests, and mutual trust.

Elliot-teague (2011) argues that different publics may have diverse interests. This is important to understand, especially in places such as developing countries, where policy statements are often issued in the interests of stakeholders who are not citizens. Policymakers can use written and verbal communication to build their narrative of justification. Such references in the public interest are made to justify the components of the policy and to convince or convince the audience that the policy is "right" for them. The policy must, in a certain sense, fulfil the 
public interest or "people's expectations" (Schneider and Ingram, 1997). This is based on the basic assumption that in democracy, policy action must be considered legitimate. Can also be legitimized through discussion of the public interest that will be achieved.

Irvin (2004) says many argue that increasing public engagement in government decision making produces many essential benefits. Differences of opinion are rare: It is hard to imagine anything but positive results from citizens who join the policy process, collaborates with others, and reach consensus to produce positive social and environmental change. Thus, public engagement becomes an important value to be applied. With citizen engagement, the formulated policy may be more realistic because it is based on citizen preferences, the public may be a more sympathetic judge of the difficult decisions that must be made by government administrators, and increased support from the public might create a less divisive and aggressive population to rule. and set.

As according to Rowe \& Frewer (2000), many calls develop to involve a more significant public in setting policies; this is in line with democratic ideals. According to Rowe \& Frewer (2000), around the 2000s there was an increase in interest in involving the public in making decisions about science and technology policies, such as issues about environmental and health risk management.

In line with this opinion, Nabatchi \& Amsler (2014) argues that public engagement is a general term that includes various methods to unite people in overcoming issues that are important to the public. To analyze related to public engagement, Nabatchi \& Amsler (2014) classifies direct public engagement in the local government into several key variables that need to be identified as follows.

The government can benefit from broader public engagement when negotiating, deciding and implementing public policies. As society moves towards a more democratic political system over the years, one will find more citizen engagement, a more open and transparent policy process and more collaborative relationships in the policy community.
There have been many concrete references from the application of the concept of public engagement in public policy, ensuring that the availability of space for the public to be engaged is essential to build a better democratic culture, this will then have a significant impact on the achievement of a policy. Public engagement in various countries that have implemented it well is considered to be an essential pillar to increase the success of the implementation of a policy, this then gives its style in public policy so that the public has room to be engaged.

As the results of the author's study in a conceptual review, the author decided to use the concept approach of the framework of direct public engagement proposed by Nabatchi \& Amsler (2014), because this concept is more coherent with the object under study so that it can make it easier for the writer to dissect the problems that occur. The author picks four key variables in accordance with Nabatchi \& Amsler (2014) as aspects of the research used to examine the problem, namely: 1) Context and Setting 2) Sponsors, Conveners, and Their Motivation for Direct Public Engagement; 3) Process Design; and 4) Outcomes.

\section{METHOD}

To understand why public engagement in that policy has not been effective, the author uses qualitative research methods. The reason the author uses qualitative research is to gain a depth of knowledge about the application of structuring policies and empowering street vendors, especially in the Garut Kota subdistrict. As for research with a similar locus, the author did several years ago, through a different research focus. Based on Lune \& Berg's (2017) opinion, the more in-depth the knowledge they have about a particular group, the more it can capture the uniqueness of the group.

The author considers that the qualitative research method is relevant as the basis of the method in this study because the phenomena that occur do not allow it to be measured accurately (quantified), so to get the right

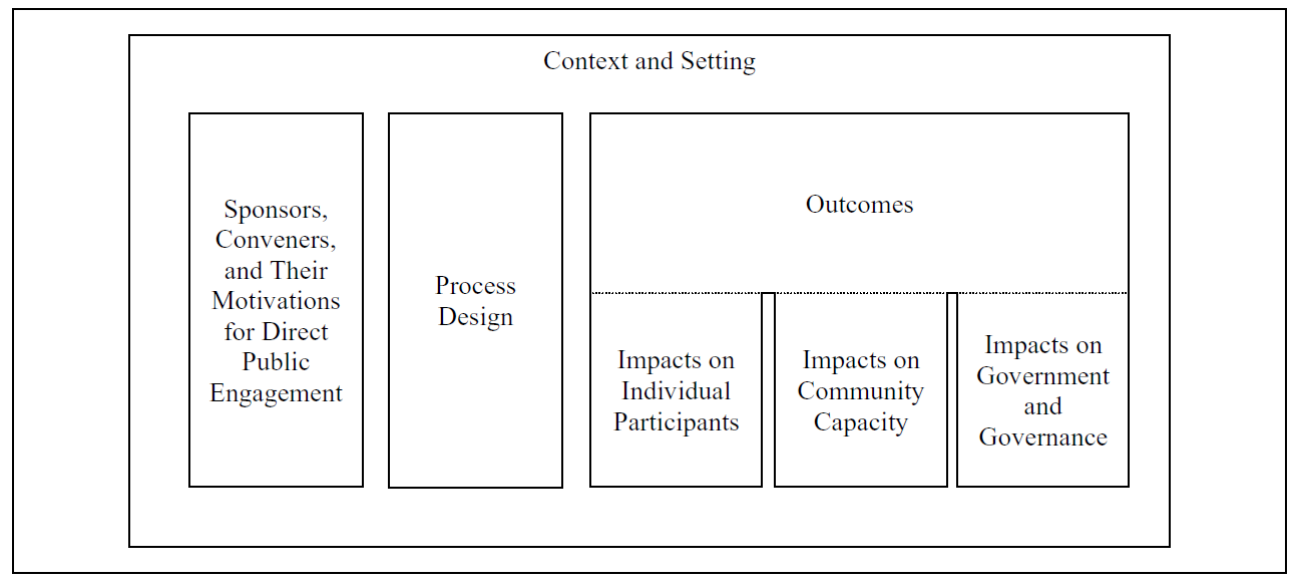

Source: Nabatchi \& Amsler (2014)

Figure 1. Framework for understanding differences in local direct public engagement. 
understanding exploratory information is needed. Through this qualitative research method, the author can examine the perspective of informants who have the authority, data, information, as well as the relationship with public engagement in the arrangement and empowerment policy of street vendors in Garut Kota subdistrict. The informant's perspective is reviewed to understand social phenomena from the perspective of the related informant.

In developing and describing the research, the author uses a descriptive research approach. Research with this descriptive approach was conducted to determine the value of independent variables by observing events or events based on data or facts that are ongoing, which are then compiled and analyzed so that conclusions can be drawn that can describe a problem that is happening. Descriptive research approaches also include an explanation of the data collected so that it can explain the complexity of an issue. The combination of qualitative research methods and descriptive research approaches is then known as qualitative descriptive research. The informants in this research are:

1) The staff of Trading Section in Department of Industry, Trade and ESDM Garut;

2) Head of Peace and Public Order Division in The Civil Service Police Unit Garut;

3) Head of Operation and Security Unit in The Civil Service Police Unit Garut;

4) Secretary of Garut Kota Subdistrict;

5) Head of The Civil Service Police Unit Garut Kota Subdistrict;

6) Head of Technical Service Unit in Department of Industry, Trade and ESDM; and

7) Chairman of the Garut Street Vendors Institution/ LPKLG.

\section{RESULTS AND DISCUSSION}

To realize success in the implementation of policy -on this case regarding the policy of structuring and empowering street vendors in Garut Kota subdistrictpublic engagement is needed. The government can benefit from broader public engagement when negotiating, deciding and implementing public policies. As society moves towards a more democratic political system over the years, one will find more citizen engagement, a more open and transparent policy process and more collaborative relationships in the policy community. There have been many concrete references from the application of the concept of public engagement in public policy, ensuring that the availability of space for the public to be engaged is essential to build a better democratic culture, this will then have a significant impact on the achievement of a policy. Public engagement in various countries that have implemented it well is considered to be an essential pillar to increase the success of the implementation of a policy, this then gives its own style in public policy so that the public has room to be engaged.

\section{Context and Setting}

Based on the results of research conducted by the author, Regent's Decree Number 511.23/Kep. 790-Admrek/2014 concerning the Team of Arragement and Empowerment for Street Vendors in Garut Regency, which in its argument provides an opportunity for the public -in this case street vendors- to be engaged in this policy. As for the Regent's Decree, the Street Vendors are given room to be engaged through two of the three fields contained in the team, namely: 1) Fields of Socialization, Data Collection, and Arrangement; and 2) Structuring/ Relocation Operations. The local government hopes through the implementation of public engagement is nothing else so that this policy can be implemented in accordance with the objectives to be achieved. Unfortunately, there is no adequate Context and Setting a variable in this policy, as revealed by Nabatchi and Amsler (2014) that in the Context and Setting includes a legal framework that covers their engagement, because with this legal framework it can shape the nature of the voice in government affairs, regarding where, when, why, how and by whom this public engagement takes place. Of course, when referring to this, the statement from the Chairman of the Garut Street Vendors Institution is indeed true, because no specific rules are governing public engagement, while in Regent's Decree Number 511.23 / Kep. 790-Admrek / 2014 the position of street vendors is only as a team member, without being accompanied by the precise definition of the roles, main tasks and functions of the street vendors on that team. The substance of the engagement of street vendors has become a formality to fulfil the principles of democratic governance. Still, in its implementation, most of the decisions and actions of the local government that are considered crucial in this policy do not represent the will of the street vendors.

\section{Sponsors, Conveners, and Their Motivations for Direct Public Engagement}

Based on the results of research conducted by the author, public engagement in this policy does not yet have a sponsor in its sustainability, both the implementation of the policy and the implementation of public engagement related to the post of District Government Budget.

As for the parties who are organizing public engagement in this policy based on Regent's Decree Number 511.23/Kep.790-Admrek/2014, especially in the field that gives positions for street vendors to be engaged as implementing elements, the fields in question are: 1) Fields of Socialization, Data Collection, and Structuring; and 2) Structuring/ Relocation Operations.

Public engagement in this policy is considered necessary, because it involves the livelihoods and livelihoods of street vendors, the local government does not want to appear rash in making decisions and actions, because in every decision and action taken has no small risk consequences, potential conflicts can occur when 
anywhere and as long as the decisions and actions are not following the wishes of the street vendors, so any decisions and actions to be taken will be communicated first with the street vendors. If examined further in the epistemological dimension, the local government wants to realize deliberative democracy in the policy, the participation of all parties is expected to be achieved: 1) Business opportunities for street vendors through location determination in accordance with their designation; 2) Growing and developing the ability of street vendors to become strong and independent micro-economic businesses; and 3) To create a clean, beautiful, orderly and safe city with adequate urban facilities and infrastructure (in Article 5 Section 1 of Ministry of Home Affairs's Decree Number 41 of 2012 concerning Guidelines for Arragenment and Empowerment of Street Vendors, 2012).

If related to the Sponsors, Conveners, and Their Motivations for Direct Public Engagement variables (Nabatchi \& Amsler, 2014), then this policy is already classified as having sponsors and organizers, namely from the local government, but the constraint that is owned is limited funding because it only relies on funding a source from the of the policy and the implementation of public engagement related to allocated from the post of District Government Budget, which in the future CSR is an alternative.

Regrettably, in this interview, the author did not get an answer related to the motivation of the parties in sponsoring public engagement in this policy.

\section{Process Design}

Based on the research, the substance of the answers from the informants tended to be less relevant, and this became very carefully related to the Context and Setting variable, in which the local government in organizing public engagement did not yet have its own rules that could contain the seven aspects in the Process Design variable, so that this has implications for the knowledge of informants who tend to be less able to master the topic in question.

\section{Outcomes}

Based on the results of interviews conducted by the author, only one informant who was straightforward and relevant answered the question above, the informant in question was the Chairman of the Garut Street Vendors Institution. Several other informants were not straightforward and relevant in answering the question in question. Yet according to Nabatchi and Amsler (2014), in theory shows that direct public engagement can bring many benefits. Individually, engagement informs the public about problems that occur in policy, can foster and foster skills in politics, public trust, and public spirit, develop empathy and tolerance, and increase the likelihood of other parties to participate in politics and their communities. At the community level, engagement can help build capacity to understand and overcome social problems and problems by cultivating social capital, fostering leadership or individual and organizational commitment and ability to solve problems, and increasing access to resources. At the institutional level, advocates claim that public engagement can improve policymaking and governance quality by reducing limited rationality, increasing public justification for policy options, and encouraging policy consensus, which in turn increases decision justice, facilitates implementation, and increases the effectiveness of public action.

Based on further observations made by the author, there is some information obtained related to the results of public engagement in this policy.

\section{1) Impact on Individuals}

Public engagement has less impact on individuals from street vendors, the reason being that individual street vendors feel they are less engaged in the regulation and empowerment of street vendors, even though public engagement has been handled so far, the decisions made so far by the local government have not come from from the wishes of the street vendors. The street vendors think their support for the Garut regency so far is only used by political interests.

\section{2) Impact on the community of street vendors}

The impact of public engagement on the community of street vendors is not significant on the one hand and significant on the other. For the Garut Street Vendors Institution, that was formed long before this policy was implemented, namely since 2003, they only felt engagement in this policy in the phases to provide support for what the Garut subdistrict Government had decided, long before this policy was implemented LPKLG had high hopes for developing Shopping Tourism like Maliboro in Yogyakarta was not realized. Unlike the case with the newly formed MPKLG after this policy was implemented, namely in 2016, when the MPKLG held a demonstration in front of the Regional Legislative Assembly building to voice its aspirations, MPKLG was allowed to sell again around Jalan Siliwangi and was given a free cart by the Garut Regent.

\section{3) Impact on Government and Governance}

Due to public participation that is not correctly patterned, neither the Government nor the Governance does not experience the impact of community engagement in this policy.

\section{CONCLUSION}

Based on the results of research conducted by the author, it can be concluded that public engagement in this policy has not been effective, because it has not been related to: 1 ) 
Context and Settings; 2) Sponsors, Conveners, and Their Motivations for Direct Public Engagement; 3) Process Design; and 4) Outcomes. Regarding Context and Settings, no specific rules are governing public engagement, while in Regent's Decree Number 511.23 / Kep. 790-Admrek / 2014 the position of street vendors is only as a team member, without being accompanied by the clear definition of the roles, main tasks and functions. The substance of the engagement of street vendors has become a formality to fulfill the principles of democratic governance, but in its implementation, most of the decisions and actions of the local government that are considered crucial in this policy do not represent the will of the street vendors. Regarding Sponsors, Conveners, and Their Motivations for Direct Public Engagement, public engagement in the policy does not yet have a sponsor in its sustainability, as for those who are organizers of public engagement in this policy is based on Regent's Decree Garut Number 511.23 / Kep. 790-Admrek / 2014, especially in the field that gives positions for street vendors to be engaged as implementing elements, the fields in question are: 1) Fields of Socialization, Data Collection, and Structuring; and 2) Structuring/ Relocation Operations. Some information, especially related to Process Design and Outcomes, is challenging to obtain. In substance, the author does not find information that is genuinely relevant to the aspects contained therein, because of the unavailability of Context and Settings that specifically regulate public engagement.

\section{REFERENCES}

Anderson, J.E. (2006). Public Policy Making: An Introduction. Boston: Houhgton Mifflin Company.

Appeal Letter Number 300/ 173-Satpol PP/ 2016. (2016).

Areros, W.A. (2015). Partisipasi Pedagang dalam Penanganan Kebersihan Pusat Kota Manado. Sosiohumaniora, 17, (1), 35-40.

Santoso, S. \& Harsono, J. (2014). Pola Solidaritas Kelompok Pedagang Angkringan di Kota Ponorogo. Sosiohumaniora, 16, (1), 62-69.

Baihaqi, H. (2018, August 27). PKL Garut Enggan Direlokasi Karena Lokasi Baru Kurang Menguntungkan. Retrieved from Tribun Jabar: http://jabar.tribunnews.com/2018/08/27/pkl-garutenggan-direlokasi-karena-lokasi-baru-kurangmenguntungkan

Bartoletti, R. \& Faccioli, F. (2016). Public Engagement, Local Policies, and Citizens' Participation: An Italian Case Study of Civic Collaboration. Social Media + Society, 1-11.

Beierle, T.C. (1999). Using Social Goals to Evaluate Public Participation in Environmental Decisions. Policy Studies Review, 16, (3/4), 75-103.
Dahlgren, P. (2009). Media and political engagement: Citizens, communication and democracy. Cambridge, UK: Cambridge University Press.

De tribune: soc. dem. Weekblad. (1935, August 23).

Department of Communication and Information Garut. (2018, December 12). Dalam Penataan PKL, Satpol PP Kerjasama TNI - Polri. Retrieved from garutkab.go.id: https://www.garutkab.go.id/news/ dalam-penataan-pkl-satpol-pp-kerjasama-tni-polri

Department of Industry, Trade and ESDM Garut. (2015). The total data of street vendors in Garut Kota Subdistrict based on the latest data in 2015. Garut: Department of Industry, Trade and ESDM Garut.

Elliot-teague, G. (2011). "Public" Interests and the Development of Tanzanian Environmental Policy. Politics \& Policy, 39, (5), 835-861.

Garut Express1. (2016, September 19). Akhirnya Bupati "Ngéléhan," PKL Diizinkan Kembali Berdagang di Kawasan Pengkolan. Retrieved from Garut Express: http:/garut-express.com/ akhirnya-bupati-ngelehan-pkl-diizinkan-kembaliberdagang-di-kawasan-pengkolan/

Ghani, H. (2017, August 07). Pemkab Garut Bagikan Gerobak Gratis untuk Ratusan PKL. Retrieved from detiknews: https://news.detik.com/beritajawa-barat/d-3588690/pemkab-garut-bagikangerobak-gratis-untuk-ratusan-pkl

Ghani, H. (2019, July 05). Pemkab Garut Larang PKL Berjualan di Jalan Ahmad Yani. Retrieved from detiknews: https://news.detik.com/berita-jawabarat/d-4612204/pemkab-garut-larang-pklberjualan-di-jalan-ahmad-yani

Herdiana, D. (2018, April 09). Gedung PKL Garut Jadi Tempat Mesum? Retrieved from Kabar Priangan Online: https://kabarpriangan.co.id/gedung-pklgarut-jadi-tempat-mesum/

Irvin, R.A. \& Stansbury, J. (2004). Citizen Participation in Decision Making: Is It Worth the Effort? Public Administration Review, 64, (1), 55-65.

Koninklijk Instituut voor Taal-, Land- en Volkenkunde (KITLV) Digital Image Library. (1895).

Local Government Regulation Number 12 of 2015 concerning Order, Cleanliness, and Beauty. (2015).

Local Government Regulation Number 18 of 2017 concerning Amendments to Regulation Number 12 of 2015 concerning Order, Cleanliness, and Beauty. (2017).

Local Government Regulation Number 3 of 2014 concerning the local government Medium Term Strategic Plan for Year 2014-2019. (2014). 
Lune, H. \& Berg, B.L. (2017). Qualitative Research Methods for the Social Sciences (9th ed.). London: Pearson.

Ministry of Home Affairs's Decree Number 41 of 2012 concerning Guidelines for Arragenment and Empowerment of Street Vendors. (2012).

Nabatchi, T. \& Amsler, L.B. (2014). Direct Public Engagement in The local government. American Review of Public Administration, 44(4S), 63S-88S.

Nelson, N. \& Wright, S. (1995). Power and Participatory Development: Theory and Practice. London: Intermediate Technology Publications.

Prasetio, A. (2018, December 11). Satpol PP Garut Ajak PKL Menata Kerapian. Retrieved from Jabar Zone: http://jabarzone.com/satpol-pp-garut-ajakpkl-menata-kerapian/

Presidential Decree Number 125 of 2012 concerning Coordination of Structuring and Empowering Street Vendors. (2012).

Regent's Decree Number 511.23/ Kep. 528-Admrek/ 2015 concerning Determination of Temporary Locations for Street Vendors Business Activities in the Garut Kota Subdistrict. (2015).
Regent's Decree Number 511.23/ Kep. 790-Admrek/ 2014 concerning concerning the Team of Arrangement and Empowerment for Street Vendors in Garut Regency. (2014).

Regent's Decree Number 511.3/Kep. 201-Satpol PP/ 2015 concerning the Team of Security and Control for Street Vendors in Garut Regency. (2015).

Rowe, G. \& Frewer, L.J. (2000). Public Participation Methods: A Framework for Evaluation. Science Technology Human Values, 25, (3), 3-29.

Rusli, B. (2015). Kebijakan Publik: Membangun Pelayanan Publik yang Responsif. Bandung: CV. ADOYA Mitra Sejahtera.

Schneider, A L. \& Ingram, H.M. (1997). Policy Design for Democracy. Lawrence, KS: University of Kansas.

Supriadin, J. (2018, August 27). Terbengkalai, Gedung PKL Garut Bisa Jadi Tempat Mesum. Retrieved from liputan6.com: https:/www.liputan6.com/ regional/read/3629171/terbengkalai-gedung-pklgarut-bisa-jadi-tempat-mesum

Suryarandika, R. (2017, August 14). Bupati Garut Akui Masih Gagal Tertibkan PKL. Retrieved from Republika:

Thomas, J. C. (1995). Public Participation in Public Decisions. San Francisco, CA: Jossey-Bass. 